\title{
Differential Effects of Estrogen Receptor Alpha and Beta Specific Agonists on Social Learning of Food Preferences in Female Mice
}

\author{
Amy E Clipperton', Joanna M Spinato², Christopher Chernets', Donald W Pfaff ${ }^{3}$ and Elena Choleris*,' \\ 'Department of Psychology, University of Guelph, Guelph, ON, Canada; ${ }^{2}$ College of Biological Sciences, University of Guelph, Guelph, ON, \\ Canada; ' ${ }^{3}$ Laboratory of Neurobiology and Behavior, The Rockefeller University, New York, NY, USA
}

\begin{abstract}
There is an evolutionary advantage to learning food preferences from conspecifics, as social learning allows an individual to bypass the risks associated with trial and error individual learning. The social transmission of food preferences (STFP) paradigm examines this advantage. Females in the proestrus and diestrus phases of the estrous cycle show a prolonged preference for the demonstrated food relative to estrus and ovariectomized females. Additionally, both estrogen receptor alpha (ER $\alpha)$ and estrogen receptor beta (ER $\beta$ ) knockout mice show impaired social recognition, which suggests that both receptors may be involved in other types of socially dependent learning, including the STFP. The present study investigated the effect of the ER $\alpha$ selective agonist PPT (1,3,5-tris(4hydroxyphenyl)-4-propyl-IH-pyrazole) and the ER $\beta$ selective agonist WAY-200070 (7-Bromo-2-(4-hydroxyphenyl)-I,3-benzoxazol-5ol) on the STFP. Results showed that ovariectomized (ovx) mice treated with PPT failed to learn the socially acquired preference, while WAY-200070-treated ovx mice showed a two-fold prolonged preference for the food eaten by their demonstrator. The effects of PPT on the socially acquired food preference cannot be explained by effects on the total food intake of the groups or on the type of interaction with the demonstrator mouse. The effects of WAY-200070 may be partially due to effects on Submissive Behavior. The higher WAY-200070 doses produced prolonged preferences similar to those seen previously in intact female mice during the proestrus and diestrus phases. This suggests that the estrous cycle's effects on social learning may be due to the action of ER $\beta$ on Submissive Behavior, or to $\operatorname{ER} \beta$ countering that of $E R \alpha$.
\end{abstract}

Neuropsychopharmacology (2008) 33, 2362-2375; doi:I0.I038/sj.npp. I301625; published online 14 November 2007

Keywords: social learning; mice; PPT; WAY-200070; social behavior; STFP

\section{INTRODUCTION}

One advantage of social living is that there are conspecifics available from which to learn. For example, an animal can expand its food repertoire by learning from a conspecific, thus avoiding the risks involved in trial-and-error learning (Galef, 1996). In the socially transmitted food preference (STFP) paradigm, an 'observer' will acquire a food preference from a brief interaction with a recently fed 'demonstrator' (Galef and Wigmore, 1983). The STFP was initially described in rats (eg Galef and Wigmore, 1983; Galef et al, 1988), and has been subsequently found in several rodent species, including house mice (Mus musculus; Valsecchi and Galef, 1989). In mice, like rats, the food odor must be carried in the mouth of a live conspecific for

*Correspondence: Dr E Choleris, Department of Psychology, University of Guelph, 50 Stone Rd East, Guelph, ON, Canada NIG 2WI, Tel: + 5198244120 ext 52729, Fax: 5198378629 ,

E-mail: echoleri@uoguelph.ca

Received 28 July 2007; revised 12 October 2007; accepted I 4 October 2007 the observer to learn the preference (Valsecchi and Galef, 1989). Interacting with a food powdered gauze-and-cottonbatten surrogate (Valsecchi and Galef, 1989), the food alone, or with a conspecific in the vicinity of the food is not sufficient for the development of a food preference (Choleris et al, in preparation). In other words, this is an exquisitely social form of learning.

While social learning is a biologically significant phenomenon, relatively little is known of its neurobiological mechanisms. A number of brain regions have been implicated in social learning, particularly the hippocampus (eg Bunsey and Eichenbaum, 1995), parahippocampal region (eg Alvarez et al, 2001), and cholinergic basal forebrain (eg Berger-Sweeney et al, 2000).

Estrogens appear to play a role in the mediation of social learning. It was recently shown that the estrous cycle can affect the memory of an STFP (as reported in SánchezAndrade et al, 2005). When tested $24 \mathrm{~h}$ after interacting with a demonstrator, only mice in proestrus showed a socially acquired preference (Sánchez-Andrade et al, 2005). Additionally, we have recently shown that, when tested 
immediately, the preference for the demonstrated food lasted 1.5-2.5 times longer in diestrus and proestrus females than in estrus and ovariectomized mice (Choleris et al, in preparation). As estrogens are low in ovariectomized mice and intact females in estrus, and higher in proestrus and diestrus females (Walmer et al, 1992), they may be involved in the STFP.

Estrogens act through two nuclear receptors, estrogen receptor alpha $(\operatorname{ER} \alpha)$ and estrogen receptor beta $(\operatorname{ER} \beta)$, as well as through extranuclear cytosolic and membranebonded classic ERs, or through the recently described membrane-specific ERs (for a recent review, see Vasudevan and Pfaff, 2007). ER $\alpha$ and $\operatorname{ER} \beta$ show largely nonoverlapping brain distributions, are expressed differently during development (Shugrue et al, 1997), and are encoded by different genes (Kuiper et al, 1996), which may explain the different roles they play in the regulation of physiology and/or behavior (Gustafsson, 2006).

Investigations of the role of estrogens in learning and memory in rodents led to largely inconsistent results, showing both enhancement and impairment (for a review, see Daniel, 2006). Possible explanations for these discrepancies include different types of learning tested (Korol et al, 2004), different treatment administration paradigms (Chesler and Juraska, 2000), the involvement of different memory systems (Davis et al, 2005), or different involvement of the two ERs, possibly through their differential distribution in the various areas of the brain known to be involved in different types of learning (Korol, 2004). The latter would be reminiscent of the opposite roles the two receptors often play in other physiological actions, like reproduction (Gustafsson, 2006).

Studies using mice in which the gene for $\operatorname{ER} \alpha$ or $\operatorname{ER} \beta$ was inactivated (knockout mice) found that $\operatorname{ER} \beta$ knockout ( $\beta$ ERKO) but not ER $\alpha$ knockout $(\alpha \mathrm{ERKO})$ mice were impaired by estradiol on the Morris water maze (Rissman et al, 2002; Fugger et al, 1998). Additionally, estrogens and $\operatorname{ER} \beta$ selective agonists improved performance on the Morris water maze, while $\mathrm{ER} \alpha$ agonists did not (Rhodes and Frye, 2006). This suggests that $\operatorname{ER} \beta$ is involved in spatial memory formation, while estradiol impairs learning through ER $\alpha$ (Rissman et al, 2002).

Estrogens have also been implicated in a number of social behaviors, including social recognition, the ability to recognize individual conspecifics, which is crucial for the normal expression of other social behaviors (Choleris et al, 2004). Both ERs are necessary for social recognition in mice (Choleris et al, 2003; Imwalle et al, 2002), with recent indication of differential involvement of the two receptors (Choleris et al, 2006). This suggests that the two ERs may play a role in social learning too.

We investigated the effects of administration of $\mathrm{ER} \alpha$ and $\operatorname{ER} \beta$ selective agonists on the social transmission of food preferences. A detailed ethological analysis assessed effects on both the learning and the social aspects of the task.

\section{MATERIALS AND METHODS}

\section{Subjects}

Subjects were 241 experimentally naïve female CD1 mice (Mus musculus), between 2.5 and 4 months of age, obtained from Charles River, QC, Canada and ovariectomized (ovx) as adults at least 2 weeks before the experiment began. Forty-nine mice were randomly selected to perform as demonstrators and ear-punched for permanent identification. The remaining 192 mice served as observers. Mice were individually housed until paired into demonstratorobserver dyads at least 3 days prior to testing. They were kept in polyethylene cages $(26 \times 16 \times 12 \mathrm{~cm})$ and provided with corncob bedding, environmental enrichment, and food (Teklad Global 14\% Protein Rodent Maintenance Diet, Harlan Teklad, Madison, WI) and tap water ad libitum. Mice were housed under a 12:12 h reversed light/dark cycle (lights on 2000 hours) at $21 \pm 1{ }^{\circ} \mathrm{C}$. Conducted in accordance with the regulations of the Canadian Council on Animal Care, this research was approved by the University of Guelph Institutional Animal Care and Use Committee.

\section{Diets}

Both demonstrator feeding and the observers' choice tests consisted of ground standard diet, mixed with either 1\% ground cinnamon (McCormick Ground Cinnamon, McCormick Canada, London, Canada) or $2 \%$ powdered cocoa (Fry's Premium Cocoa, Cadbury Ltd, Mississauga, Canada) by weight. These two flavored diets, which have equivalent metabolic and physical features, were equipalatable to other female CD1 mice obtained from Charles Rivers, QC (data not shown).

\section{Apparatus}

Demonstrators' flavored food was served using cylindrical jars $5 \mathrm{~cm}$ high and $7.5 \mathrm{~cm}$ in diameter (Dyets Inc., Bethlehem, PA) fitted with a stainless steel ring (hole $2.5 \mathrm{~cm}$ in diameter) and a sleeve collar to prevent spillage. Demonstrators' feeding occurred in a clean polyethylene cage $(26 \times 16 \times 12 \mathrm{~cm})$. Social interactions between observers and demonstrators occurred in their home cages, using clear Plexiglas lids with air holes, and were videotaped from above in Nightshot using an $8 \mathrm{~mm}$ Sony Handycam for subsequent behavioral analysis. Observers' choice tests were run in $31 \times 23 \times 24 \mathrm{~cm}$ DietMax clear acrylic cages (Accuscan Instruments, Inc., Columbus, $\mathrm{OH}$ ) with a stainless steel grid floor. One side of each cage held a water bottle equidistant between two Plexiglas tunnels $(5.5 \times 3.75 \times 3 \mathrm{~cm})$ leading to two $6 \times 4 \times 2.5 \mathrm{~cm}$ feeding trays. Each tray was placed on a scale (AND, Bradford, MA) connected to a DietMax analyzer and a Dell computer that stored the reading of each scale every $1.5 \mathrm{~s}$.

\section{Drugs}

In a first experiment, the ER $\alpha$ agonist 1,3,5-tris(4-hydroxyphenyl)-4-propyl-1H-pyrazole (PPT), which is 410 times more selective for $\operatorname{ER} \alpha$ than $\operatorname{ER} \beta$ in mice (Stauffer et al, 2000), was used. Four groups were formed: a sesame oil (vehicle) control $(n=22)$, and three doses of PPT, $0.025 \mathrm{mg} / \mathrm{kg}$ $(n=21), \quad 0.05 \mathrm{mg} / \mathrm{kg} \quad(n=22), \quad$ and $0.1 \mathrm{mg} / \mathrm{kg} \quad(n=21)$. Observers were injected subcutaneously at $1 \mathrm{ml} / \mathrm{kg} 48 \mathrm{~h}$ prior to the experiment in order to allow the drug to fully exert its effects, genomic and otherwise. The doses and timeframe have been shown to be effective in producing 
antianxiety behavior in rats (eg Walf and Frye, 2005). In order to prevent solution leakage, the injection site was sealed with Nexcare liquid bandage drops (3 M Canada, London, ON, Canada).

In a second experiment, we used the selective $\operatorname{ER} \beta$ agonist 7-Bromo-2-(4-hydroxyphenyl)-1,3-benzoxazol-5-ol (WAY200070), which is 68 times more selective for $\operatorname{ER} \beta$ than $\mathrm{ER} \alpha$ in mice (compound 92 in Malamas et al, 2004; courtesy of Wyeth Laboratories, Inc., Madison, NJ). Four groups of observers were formed: a sesame oil (vehicle) control $(n=22)$ and three experimental groups, each receiving one of three doses of WAY-200070 $(30 \mathrm{mg} / \mathrm{kg}, n=25 ; 90 \mathrm{mg} / \mathrm{kg}$, $n=21$; or $180 \mathrm{mg} / \mathrm{kg}, n=22$ ) intraperitoneally at $1 \mathrm{ml} / \mathrm{kg}$ $72 \mathrm{~h}$ prior to the experiment. The doses and timeframe were chosen based on previous data indicating that social recognition in ovx female CD1 mice was improved by intraperitoneal injection of $90 \mathrm{mg} / \mathrm{kg}$, but not by $30 \mathrm{mg} / \mathrm{kg}$ of WAY-200070 (Cragg et al, 2007, in preparation).

\section{Procedure}

At least $12 \mathrm{~h}$ before testing, demonstrators' fur was marked with black magic marker, and the pairs were moved into the experimental room, deprived of food, and left undisturbed.

Beginning early in their active phase, vaginal smears were taken from all mice. Demonstrators were removed from their home cages, individually placed in an empty cage with a jar containing either cinnamon- or cocoa-flavored food (randomly distributed such that half received each diet), and allowed to feed for $1 \mathrm{~h}$. The results of six pairs (randomly distributed across treatment groups) in which the demonstrator had consumed less than $0.10 \mathrm{~g}$ of food were eliminated from the data pool. Demonstrators were returned to their home cage for a 30-min videotaped social interaction with the observer. Observers were then immediately placed in the testing chambers and given a choice between the two diets, which were continuously available for $24 \mathrm{~h}$.

The videotaped social interactions were scored by three trained observers, who were unaware of the animals' treatment, for 21 behaviors based on the ethogram by Grant and Mackintosh, 1963; see Table 1 for behavior descriptions) using The Observer Video Analysis software (Noldus Information Technology, Wageningen, The Netherlands). Behavioral analysis focused on the treated mouse, the observer; the demonstrator's behavior was collected only in relation to that of the observer.

Individual behaviors were grouped into several categories to assess effects of drug on overall activity, total social and nonsocial explorations of the mice, and levels of agonistic behavior displayed during the interaction (see Table 2). Whenever possible, the direction of agonistic behavior was defined, and a Dominance Score was also calculated for each dyad of mice (see Table 2).

The vaginal smear slides were stained with Giemsa stain (Sigma-Aldrich, Oakville, ON) and examined under a microscope using $\times 100$ magnification. Proestrus was defined as consisting of predominantly nucleated cells, estrus of primarily non-nucleated, cornified cells, and diestrus of predominantly leukocytes.
Table I Description of Scored Behaviors

Social behaviors

Following the

demonstrator

Dominant behavior the demonstrator; reciprocal to avoid; movement along the tail

The observer mouse is in control; includes pinning of demonstrator, aggressive grooming, crawling over or on top, and mounting attempt

Attacks delivered Physical attacks, including dorsal/ventral bites. Only frequency of attacks was measured

Ritualized aggression Physical attacks that include box/wrestle, offensive and defensive postures, lateral sideways threats, and tail rattle

Open aggression Physical attacks with a locked fight, including tumbling, kick-away and counterattack where the attacker cannot be identified

Avoidance of the demonstrator

Submissive behavior

Observer withdraws and runs away from demonstrator while the demonstrator is following

Demonstrator mouse is in control; includes crawl under, supine posture (ventral side exposed), prolonged crouch, and any other behavior in which the demonstrator is dominant (eg demonstrator pins, aggressively grooms, etc., observer)

Attacks received

Physical attacks including bites to dorsal/ventral regions. Only frequency of attacks was measured

Defensive upright posturing

Social inactivity

Oronasal investigation

Body investigation

Anogenital investigation

Stretched approach

Species-typical defensive behavior; upright with the head tucked and the arms ready to push away

Includes sit/lie/sleep together

Active sniffing of demonstrator's oronasal area; within $1.5 \mathrm{~cm}$

Active sniffing of demonstrator's body; within $1.5 \mathrm{~cm}$

Active sniffing of demonstrator's anogenital region; within $1.5 \mathrm{~cm}$

Risk assessment behavior; back feet do not move and front feet approach demonstrator. Only frequency of stretched approaches was measured

Approaching and/or Attending to the Demonstrator

Often from across the cage; observer's attention is focused on demonstrator, head tilted toward demonstrator and movements toward demonstrator; this becomes 'Follow Opponent' once along the tail or sniff if within $1.5 \mathrm{~cm}$ of the demonstrator

Nonsocial behaviors

Horizontal exploration

Movement around the cage; includes active sniffing of air and ground

Vertical exploration

Movement to investigate upwards, both front feet off the ground; includes sniffing, wall leans, and lid chews (less than 3)

Digging Rapid stereotypical movement of forepaws in the bedding

Abnormal stereotypies 'Strange' behaviors, including spinturns, repeated jumps/lid chews/head shakes (more than 3)

Solitary Inactivity

No movement; includes sit, lie down, and sleep

Self-grooming

Rapid movement of forepaws over facial area and along body

\section{Statistical Analyses}

Consumption of the cocoa and cinnamon diets was calculated at $2 \mathrm{~h}$ intervals throughout the $24 \mathrm{~h}$ choice test. 
Table 2 Descriptions of Grouped and Composite Behaviors

Total Activity
Total Social
Behavior

Total Agonistic

Behaviors

Delivered

Agonistic Behavior

Received

Dominance Score

\begin{abstract}
Total agonistic behavior delivered minus total agonistic behavior received. A negative score indicates that the observer was the submissive animal in the pair, while a positive score signifies that the observer was the dominant animal
\end{abstract}

Social Investigation

Oronasal investigation, body investigation, anogenital investigation, stretched approach, and attend to/approach demonstrator

Nonsocial

Behaviors

Horizontal exploration, vertical exploration, dig, stereotypies, inactive alone, and self-groom

Nonsocial

Locomotor

Horizontal exploration, vertical exploration, and dig

Behaviors

Nonsocial

Nonlocomotor

Inactive and self-groom

Behaviors

Observer choice data were then expressed as a cinnamon preference ratio, that is, the amount of cinnamon diet eaten out of the total amount of food consumed (cinnamon/ (cocoa + cinnamon)), and arcsine transformed. A three-way mixed design analysis of variance (ANOVA) assessing the effects of demonstrated food, drug treatment, and time on the observers' cinnamon preference was not possible, as mice do not eat continuously throughout a $24 \mathrm{~h}$ period, but rather consume the majority of their food during the active, nocturnal phase of their light cycle (Latham and Mason, 2004; Figures 2 and 5). As a consequence, most of our mice failed to eat during at least one of the twelve $2 \mathrm{~h}$ intervals, and the presence of these empty cells in the data caused a repeated measure design to eliminate the majority of the sample. Each $2 \mathrm{~h}$ block was therefore analyzed with a twoway ANOVA to assess the effects of demonstrated food (cocoa or cinnamon) and drug treatment. Because effects of the drugs were expected in the initial part of the observers' choice test, when social learning effects are stronger (Choleris et al, 1997, 1998; Valsecchi et al, 1996), one-way ANOVAs were used for planned comparisons of the effect of the demonstrated food for each group at each of the first five $2 \mathrm{~h}$ intervals, corresponding to the mice's active phase.

A two-way mixed design ANOVA was performed to determine if there were effects of drug treatment and time (twelve $2 \mathrm{~h}$ intervals) on the observers' total food intake. Post hoc independent sample $t$-tests were performed to assess sources of significance.

The 30-min social interaction period was divided into six 5-min intervals and the frequency and duration of each behavior were measured. As behavioral elements were mostly not normally distributed, these data were analyzed using the Kruskal-Wallis and Mann-Whitney $U$ nonparametric tests.

To determine whether the level of oronasal investigation affects preference for the demonstrated food, Spearman's $\rho$ correlations were performed between oronasal investigation (duration and frequency) and the degree and duration of preference for the demonstrated food. As there were no effects on oronasal investigation by either drug, all animals were included in these correlations, thus providing a large sample size $(N=86$ in the PPT study, $N=90$ in the WAY-200070 study). Based on the results of the second experiment, two additional tests were performed, consisting of four Spearman's $\rho$ correlations: (1) Dominance Score and degree of preference expressed for the demonstrated food; (2) Dominance Score and duration of preference for the demonstrated food; (3) Submissive Behavior and degree of preference for the demonstrated food, and (4) Submissive Behavior and duration of preference for demonstrated food, and six analyses of covariance (ANCOVA) assessing the effect of frequency and duration of Dominance Scores, Agonistic Behavior Received, and Submissive Behavior on the cinnamon preference ratio.

If not otherwise stated, reported drug effects are in comparison to the vehicle control group. The results of the analysis performed on duration and frequency of each behavior were mostly consistent with each other, so frequency results are only reported when different from those of the durations. All analyses were performed using SPSS 13.0 for Windows (SPSS Inc., Chicago, IL), with an $\alpha$ level of 0.05 .

\section{RESULTS}

\section{Experiment 1: Effects of PPT}

Food preferences and food consumption. Comparisons of the preference for cinnamon in mice whose demonstrators consumed cocoa-flavored food to the preference for cinnamon in mice that interacted with demonstrators who ate cinnamon-flavored food revealed a significant effect of the demonstrated food for the first $2 \mathrm{~h}$ interval $(F(1,78)=6.62, p=0.012)$. Specifically, there was a 

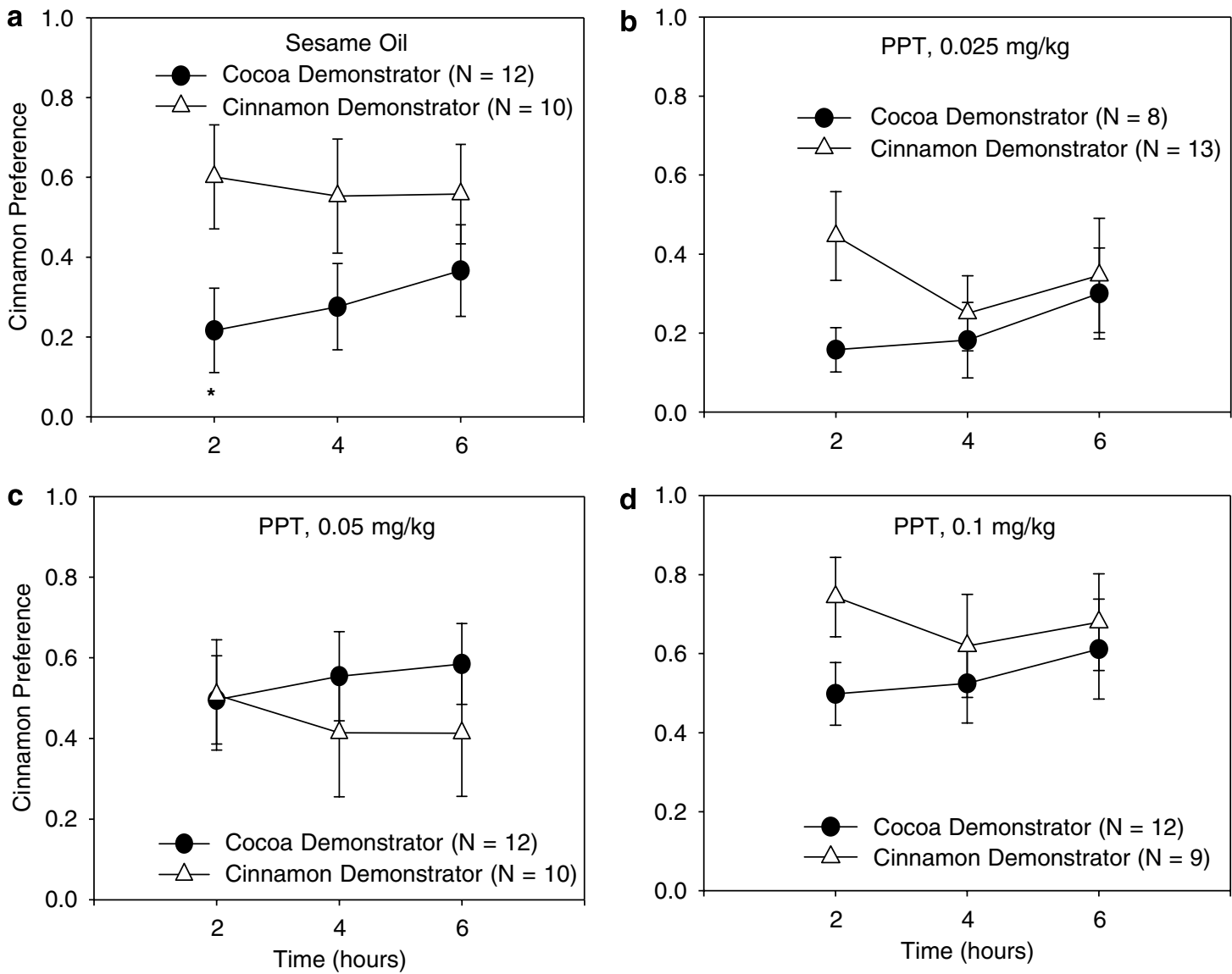

Figure I Cinnamon preference expressed at 2, 4, and $6 \mathrm{~h}$ of testing in observers whose demonstrator had been fed either a cocoa (black circle)- or a cinnamon (white triangle)-flavored diet. Means and standard errors are shown. *Indicates a significant difference between observers whose demonstrator had been fed the cocoa-flavored diet and those whose demonstrator had been fed the cinnamon-flavored diet, $p<0.05$. Observers were treated with (a) sesame oil (b) $0.025 \mathrm{mg} / \mathrm{kg}$ PPT, (c) $0.05 \mathrm{mg} / \mathrm{kg}$ PPT, and (d) $0.1 \mathrm{mg} / \mathrm{kg}$ PPT $48 \mathrm{~h}$ prior to testing.

significant effect of the demonstrated food in the first $2 \mathrm{~h}$ interval in the sesame oil control group $(\mathrm{F}(1,20)=4.63$, $p=0.044$; see Figure 1a). There were no significant effects of the demonstrated food at any subsequent $2 \mathrm{~h}$ interval, and the observers treated with all three doses of PPT showed no effects of the demonstrated food on their cinnamon preferences (see Figure $1 \mathrm{~b}-\mathrm{d}$ ). This analysis shows that the control group was the only one to display statistically significant social learning.

As seen in Figure 2, there was a significant effect of time $(\mathrm{F}(11,924)=57.01, p<0.001)$ but no other effects on total food consumption.

Behavioral analysis. The pattern of mouse behavior changed over the duration of the social interaction. Specifically, the mice were more active in the beginning of the trial, including both social (agonistic and investigative) and nonsocial behaviors (eg Horizontal and Vertical Exploration, Digging). In the last part of the interaction, the mice were less active and spent more time in both social (ie social inactivity) and nonsocial nonlocomotor activity (ie Solitary Inactivity and Self-grooming). This temporal pattern of behavior is reflected in the effect of PPT on certain behaviors at specific intervals of the interaction.

As PPT did not affect the levels of Total Activity of the mice, drug effects on the social learning of food

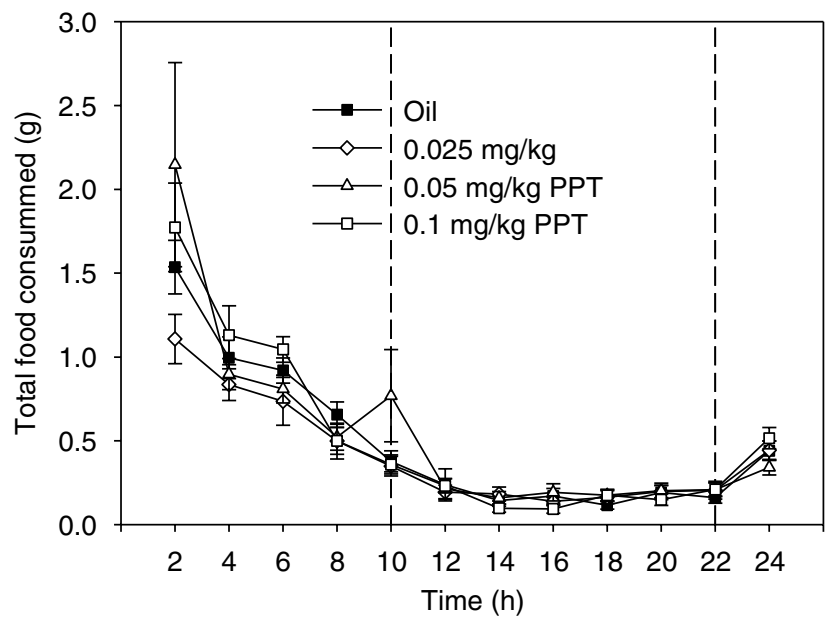

Figure 2 Total food intake (g) by $2 \mathrm{~h}$ intervals over the $24 \mathrm{~h}$ choice test for observers that had received sesame oil (black square), $0.025 \mathrm{mg} / \mathrm{kg}$ PPT (white diamond), $0.05 \mathrm{mg} / \mathrm{kg}$ PPT (white triangle), or $0.1 \mathrm{mg} / \mathrm{kg}$ PPT (white square) $48 \mathrm{~h}$ prior to testing. Means and standard errors are shown. Vertical dashed lines indicate lights on $(10 \mathrm{~h})$ and lights off $(22 \mathrm{~h})$.

preferences cannot be explained by decreased activity levels. There were some specific drug effects on certain behavioral elements. 
Social behaviors. While the mice in all groups showed similar total levels of Total Social Behavior and Social Investigation, some specific aspects of Social Investigation were affected by PPT administration. There was a significant effect of treatment on the frequency of Approaching and/or Attending to the Demonstrator $\left(\chi^{2}(3)=9.57\right.$, $p=0.023$; see Figure 3a). This can be largely attributed to the $0.1 \mathrm{mg} / \mathrm{kg}$ PPT dose significantly decreasing the frequency of Approaching and/or Attending to the Demonstrator in comparison to both the oil $(U=130.00, z=-2.29$, $p=0.022)$ and $0.05 \mathrm{mg} / \mathrm{kg}$ PPT groups $(U=109.50$, $z=-2.81 p=0.005$; see Figure $3 \mathrm{a})$. There was also a significant difference between the 0.05 and $0.1 \mathrm{mg} / \mathrm{kg}$ PPT doses on the duration of Approaching and/or Attending to the Demonstrator $(U=131.50, z=-2.24, p=0.025)$. Specifically, $0.1 \mathrm{mg} / \mathrm{kg}$ PPT decreased Approaching and/or Attending to the Demonstrator in the first $5 \mathrm{~min}$ of the trial $(U=143.00, z=-1.98, p=0.048)$, and the $0.025 \mathrm{mg} / \mathrm{kg}$ PPT group showed lower levels of Approaching and/or
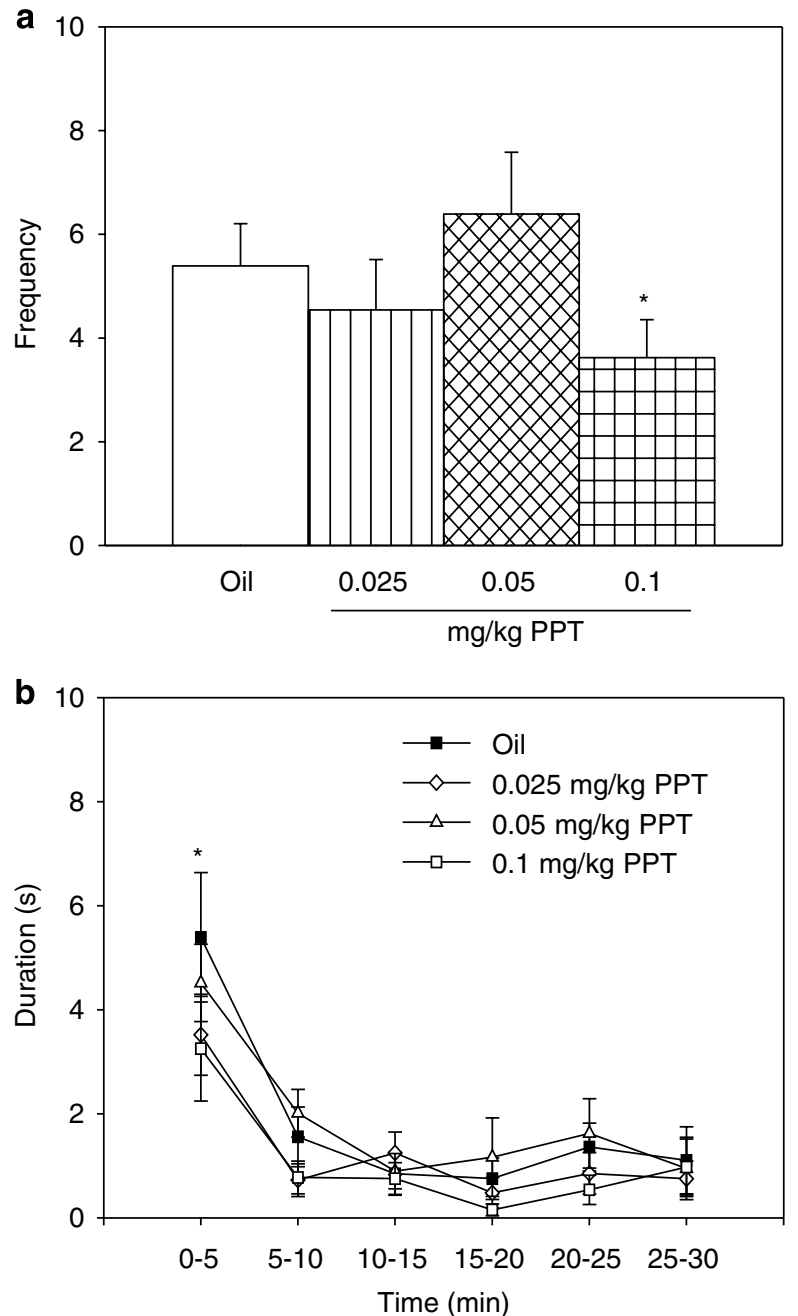

Figure 3 (a) Frequency of approaching/attending to demonstrator in the 30 min interaction and (b) duration of approaching/attending to demonstrator by $5 \mathrm{~min}$ intervals by observers that had received sesame oil (black square) or doses of $0.025 \mathrm{mg} / \mathrm{kg}$ (white diamond), $0.05 \mathrm{mg} / \mathrm{kg}$ (white triangle), or $0.1 \mathrm{mg} / \mathrm{kg}$ of PPT (white square). Means and standard errors are shown. *Indicates a significant difference between the sesame oil control group and the $0.1 \mathrm{mg} / \mathrm{kg}$ PPT group, $p<0.05$.
Attending to the Demonstrator than the $0.05 \mathrm{mg} / \mathrm{kg}$ PPT group at $5-10 \mathrm{~min}(U=136.00, z=-2.65, p=0.008$; see Figure $3 \mathrm{~b}$ ). Additionally, the $0.1 \mathrm{mg} / \mathrm{kg}$ PPT group was significantly lower than $0.05 \mathrm{mg} / \mathrm{kg}$ in Approaching and/or Attending to the Demonstrator in the first $10 \mathrm{~min}$ of the trial (0-5 min: $U=136.50, \quad z=-2.13, \quad p=0.033 ; \quad 5-10 \mathrm{~min}$ : $U=115.50, z=-2.82, p=0.005$; see Figure $3 b$ ).

Importantly, the inhibiting effects of PPT on the socially learned food preference cannot be explained by decreased sniffing at the mouth of the demonstrator (Oronasal Investigation), as this behavior was not affected by the drug. The only effect seen was at the 5-10 min mark of the trial, at which point the $0.05 \mathrm{mg} / \mathrm{kg}$ PPT group, which was impaired in social learning, actually showed increased frequency of Oronasal Investigation $(U=137.50$, $z=-2.105, p=0.035$ ). Correlations between Oronasal Investigation and the degree or duration of expression of the preference for the demonstrated food yielded no significant relations. Clearly, an increase in this behavior cannot account for the absence of social learning in this group.

There were no effects of PPT on Total Agonistic Behaviors, Agonistic Behavior Delivered, Agonistic Behavior Received, or Dominance Score. All groups show that the observer was dominant (ie showed a higher Dominance Score frequency) in at least the first $5 \mathrm{~min}$ of the interaction (oil: $t(20)=3.38, p=0.003 ; 0.025 \mathrm{mg} / \mathrm{kg}$ PPT: $t(22)=3.71$, $p=0.001 ; 0.05 \mathrm{mg} / \mathrm{kg}$ PPT: $t(20)=2.84, p=0.010 ; 0.1 \mathrm{mg} / \mathrm{kg}$ PPT: $t(20)=3.64, p=0.002)$. This prior-resident effect (Archer, 1988) is not unexpected, as the demonstrator had been removed from the home cage for an hour. All other social behaviors analyzed showed no effect of PPT.

Nonsocial behaviors. There was no effect of treatment with PPT on any nonsocial behaviors.

Vaginal smears revealed that all mice were in diestrus, and not cycling, showing that treatment with PPT did not affect the vaginal cytology of the ovx mice.

\section{Experiment 2: Effects of WAY-200070}

Food preferences and food consumption. Comparisons between the preference for cinnamon in mice whose demonstrators consumed cinnamon-flavored food and the preference for cinnamon in mice that interacted with demonstrators who ate cocoa-flavored food revealed a significant effect of the demonstrated food in both the $2 \mathrm{~h}$ $(\mathrm{F}(1,81)=50.55, \quad p<0.001) \quad$ and the $4 \mathrm{~h}$ intervals $(\mathrm{F}(1,79)=11.48, p=0.001)$. Specifically, there was a significant effect of the demonstrated food only in the first $2 \mathrm{~h}$ interval in the sesame oil vehicle $(\mathrm{F}(1,20)=4.42, p=0.048)$, the $30 \mathrm{mg} / \mathrm{kg}$ WAY-200070 $(\mathrm{F}(1,22)=20.20, p<0.001)$ and the $180 \mathrm{mg} / \mathrm{kg}$ WAY-200070 $(\mathrm{F}(1,19)=14.14, p<0.001)$ groups (see Figure $4 \mathrm{a}, \mathrm{b}$ and $\mathrm{d}$ ). The $90 \mathrm{mg} / \mathrm{kg}$ WAY200070 group, however, significantly preferred the demonstrated food at both 2 and $4 \mathrm{~h}(2 \mathrm{~h}: \mathrm{F}(1,19)=20.80, p<0.001$; $4 \mathrm{~h}: \mathrm{F}(1,19)=12.10, p=0.003$; see Figure $4 \mathrm{c}$ ). This analysis shows that while all groups expressed a preference for the demonstrated food, the $90 \mathrm{mg} / \mathrm{kg}$ WAY-200070 group showed a preference for the demonstrated food that lasted twice as long as the other groups (see Figure 4).

As Figure 5 shows, there was a significant effect of time on total food consumption $(\mathrm{F}(11,825)=183.85, p<0.001)$, but 

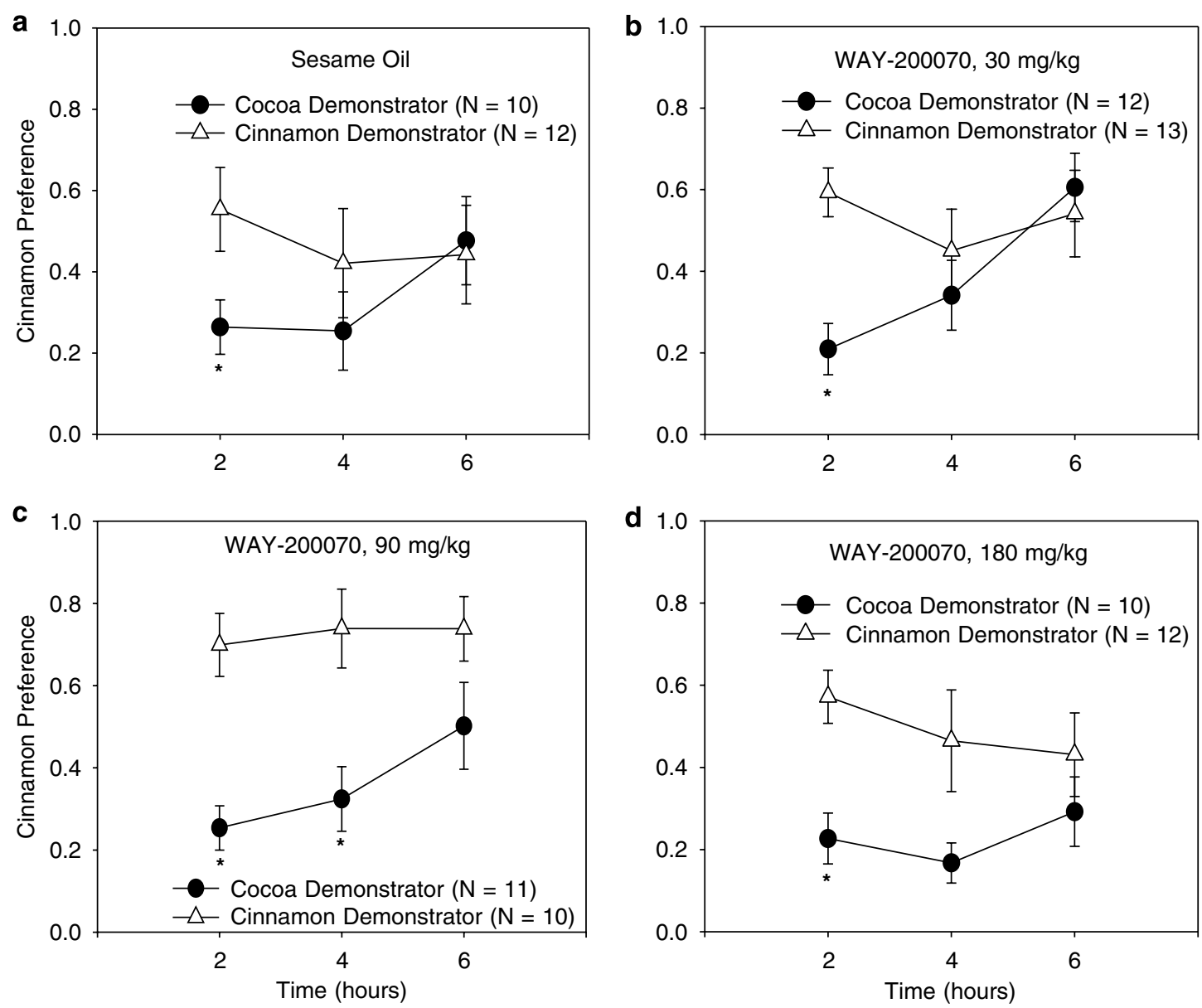

Figure 4 Cinnamon preference in observers whose demonstrator had been fed either a cocoa (black circle) or a cinnamon (white triangle) flavored diet. Means and standard errors are shown. *Indicates a significant difference between observers whose demonstrator had been fed the cocoa-flavored diet and those whose demonstrator had been fed the cinnamon-flavored diet, $p<0.05$. Observers were treated with (a) sesame oil, (b) $30 \mathrm{mg} / \mathrm{kg}$ WAY-200070, (c) $90 \mathrm{mg} / \mathrm{kg}$ WAY-200070, (d) $180 \mathrm{mg} / \mathrm{kg}$ WAY-200070 $72 \mathrm{~h}$ prior to testing.

no other significant effects. Thus, our results cannot be explained by different amounts of food consumed, as there were no significant differences in food intake between any treatment groups at any $2 \mathrm{~h}$ interval.

Behavioral analysis. As in the results of the PPT experiment, the pattern of behavior changed as the interaction progressed. The mice were generally more socially and nonsocially active in the beginning of the trial, and were generally less active, spending more time in social and nonsocial nonlocomotor activity, in the latter part of the interaction. This temporal pattern of behavior is reflected in the effect of WAY-200070 on certain behaviors at specific intervals of the interaction.

There were no drug effects on Total Activity of the mice, indicating that the prolonged preference was not produced by an overall increase in activity. There were some specific behavioral effects of WAY-200070.

Social behaviors. Overall, the mice in all groups showed similar levels of Total Social Behavior. There were some specific effects of WAY-200070 on aspects of these interactions. There was a significant effect of treatment on Social Investigation in the first $5 \mathrm{~min}$ of the trial $\left(\chi^{2}(3)=9.43, p=0.024\right.$; see Figure $\left.6 \mathrm{a}\right)$, with the $180 \mathrm{mg} / \mathrm{kg}$

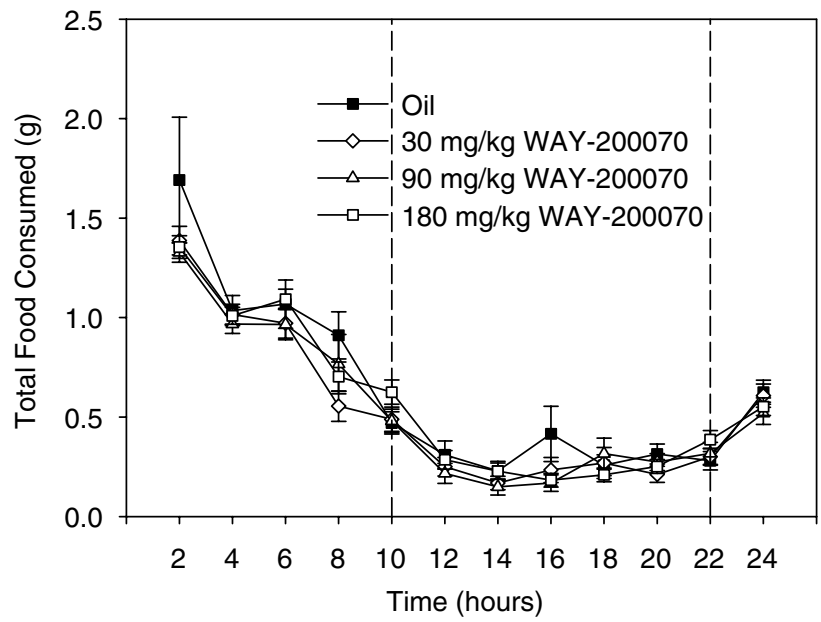

Figure 5 Total food intake $(\mathrm{g})$ by $2 \mathrm{~h}$ intervals for observers that had received sesame oil (black square), $30 \mathrm{mg} / \mathrm{kg}$ WAY-200070 (white diamond), $90 \mathrm{mg} / \mathrm{kg}$ WAY-200070 (white triangle), or $180 \mathrm{mg} / \mathrm{kg}$ WAY-200070 (white square). Means and standard errors are shown. Vertical dashed lines indicate lights on $(10 \mathrm{~h})$ and lights off $(22 \mathrm{~h})$.

WAY-200070 group showing decreased Social Investigation at this interval $(U=116.00, z=-2.62, p<0.009)$. Specifically, WAY-200070 affected Anogenital Investigation in the 

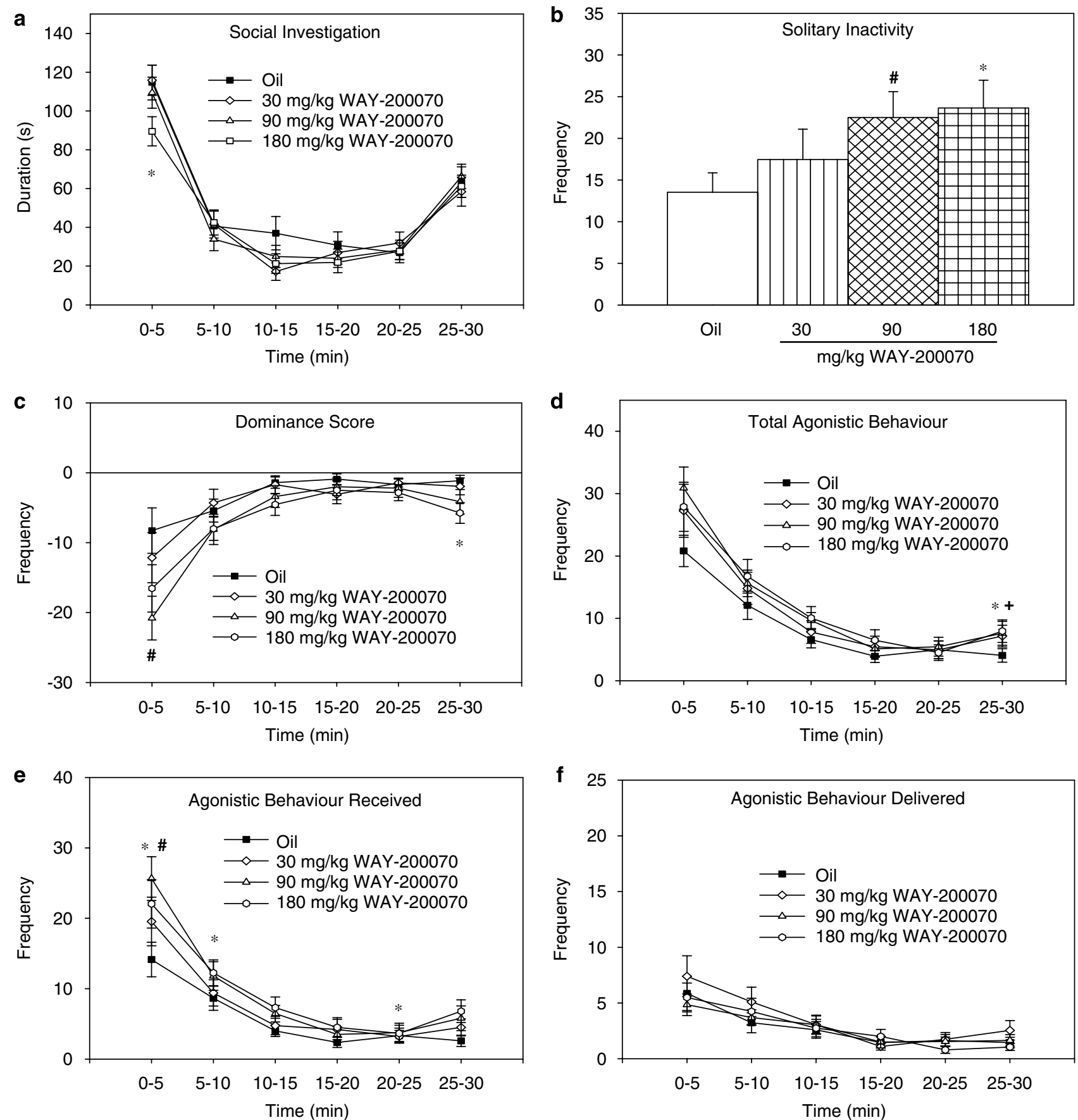

Figure 6 (a) Duration of Social Investigation by 5 min intervals. (b) Frequency of solitary inactivity in the 30 min interaction by observers that had received sesame oil or doses of 30,90, or $180 \mathrm{mg} / \mathrm{kg}$ of WAY-200070. (c) Dominance Scores (frequencies). (d) Frequency of total agonistic behavior. (e) Frequency of Agonistic Behavior Received. ( $f$ ) Frequency of Agonistic Behavior Delivered by 5 min intervals. Means and standard errors are shown. In (a and c- $f$ ), observers had received sesame oil (black square), $30 \mathrm{mg} / \mathrm{kg}$ WAY-200070 (white diamond), $90 \mathrm{mg} / \mathrm{kg}$ WAY-200070 (white triangle), or I $80 \mathrm{mg} / \mathrm{kg}$ WAY200070 (white square). ${ }^{+}$Indicates a significant difference between the $30 \mathrm{mg} / \mathrm{kg}$ WAY-200070 and the sesame oil control group. ${ }^{\#}$ Indicates a significant difference between the $90 \mathrm{mg} / \mathrm{kg}$ WAY-200070 and the sesame oil control group. * Indicates a significant $(p<0.05)$ difference between the I80 mg/kg WAY-200070 and the sesame oil control group.

first 5 min of the trial $\left(\chi^{2}(3)=9.22, p<0.026\right)$. Importantly, the effects of the 90 and $180 \mathrm{mg} / \mathrm{kg}$ doses of WAY-200070 on the socially learned food preference cannot be explained by increased sniffing at the mouth of the demonstrator (Oronasal Investigation), as this behavior was not affected by the drug. Correlations between Oronasal Investigation and the degree or duration of expression of the preference for the demonstrated food also yielded no significant relations.

Agonistic behaviors. There was a significant effect of treatment on the duration of Total Agonistic Behaviors in the first $5 \mathrm{~min}$ of the trial $\left(\chi^{2}(3)=8.50, p=0.037\right)$, and on the frequency of Total Agonistic Behaviors in the last $5 \mathrm{~min}$ 
of the trial $\left(\chi^{2}(3)=8.44, p=0.038\right.$; see Figure $\left.6 \mathrm{~d}\right)$. There was an increased frequency of Total Agonistic Behaviors in the interaction of mice treated with $180 \mathrm{mg} / \mathrm{kg}$ WAY-200070 $(U=127.00, z=-2.14, p=0.032)$, predominantly during the last $5 \mathrm{~min}$ of the social interaction $(U=105.00$, $z=-2.74, p=0.006$; see Figure $6 \mathrm{~d}$ ). The $30 \mathrm{mg} / \mathrm{kg}$ group also showed this increase during the last $5 \mathrm{~min}$ of the interaction ( $U=149.00, z=-2.01, p=0.045$; see Figure $6 \mathrm{~d}$ ).

The increased Total Agonistic Behaviors observed in the social interactions of the 90 and $180 \mathrm{mg} / \mathrm{kg}$ WAY-200070treated mice was due to increased Agonistic Behavior Received by those observers, particularly in the first $5 \mathrm{~min}$ of the trial $\left(\chi^{2}(3)=8.36, p=0.038\right)$. The $90 \mathrm{mg} / \mathrm{kg}$ WAY$200070(U=141.00, z=-1.99, p=0.047)$ and $180 \mathrm{mg} / \mathrm{kg}$ WAY-200070 $(U=139.00, \quad z=-2.04, \quad p=0.041)$ groups experienced more frequent Agonistic Behavior Received (see Figure 6e). In particular, the $90 \mathrm{mg} / \mathrm{kg}$ WAY-200070 group had a higher frequency of Agonistic Behavior Received in the first $5 \mathrm{~min}$ of the social interaction ( $U=130.00, z=-2.27, p=0.023$; see Figure $6 \mathrm{e}$ ), while the $180 \mathrm{mg} / \mathrm{kg}$ WAY-200070 group showed a higher frequency of Agonistic Behavior Received in the first $10 \mathrm{~min}$ of the interaction $(0-5 \mathrm{~min}: \quad U=134.00, \quad z=-2.17, \quad p=0.030$; 5-10 min: $U=137.00, z=-2.10, p=0.036$; see Figure 6e), as well as during the $20-25 \mathrm{~min}$ interval $(U=133.00$, $z=-2.21, p=0.027$; see Figure $6 \mathrm{e})$. These increases in Agonistic Behavior Received were paralleled by an increase in the Submissive Behavior displayed by the observer, particularly in the first $5 \mathrm{~min}\left(\chi^{2}(3)=8.53, p=0.036\right)$. Submissive Behavior was increased by the $90 \mathrm{mg} / \mathrm{kg}(U=$ $142.00, z=-1.96, p=0.049)$ and $180 \mathrm{mg} / \mathrm{kg}(U=141.00$, $z=-1.99, p=0.047)$ doses, especially in the first 5 (90 mg/ kg WAY-200070, $U=132.00, z=-2.22, p=0.027)$ and $10 \mathrm{~min}$ $(180 \mathrm{mg} / \mathrm{kg}$ WAY-200070, $0-5 \mathrm{~min}: U=137.50, z=-2.08$, $p=0.038,5-10 \mathrm{~min}: U=138.50, z=-2.06, p=0.039)$ of the interaction, as well as $\mathrm{min} 20-25(180 \mathrm{mg} / \mathrm{kg}$ WAY-200070 $U=136.00, z=-2.14, p=0.033$ ).

Consistent with the effects on agonistic behavior, there was an effect of treatment on Dominance Score (frequencies) in the first $5 \mathrm{~min}$ of the social interaction $\left(\chi^{2}(3)=7.82\right.$, $p=0.0499$; see Figure 6c). The $90 \mathrm{mg} / \mathrm{kg} \mathrm{WAY}-200070$ and $180 \mathrm{mg} / \mathrm{kg}$ WAY-200070 groups also showed lower Dominance Scores (frequency: $90 \mathrm{mg} / \mathrm{kg}$ WAY-200070: $U=138.00, z=-2.07, p=0.039 ; 180 \mathrm{mg} / \mathrm{kg}$ WAY-200070: $U=141.50, z=-1.98, p=0.048)$. For the $90 \mathrm{mg} / \mathrm{kg} \mathrm{WAY}-$ 200070 group, this was predominantly in the first $5 \mathrm{~min}$ ( $U=121.50, z=-2.48, p=0.013$ ), while for the $180 \mathrm{mg} / \mathrm{kg}$ WAY-200070 group it was chiefly in the last $5 \mathrm{~min}$ $(U=112.00, z=-2.76, p=0.006$; see Figure $6 c)$. Additionally, in all groups, the observer was the submissive animal (ie showed a negative Dominance Score frequency), both overall (oil: $t(21)=2.91, p=0.008 ; 30 \mathrm{mg} / \mathrm{kg}$ WAY-200070: $t(20)=3.52, p=0.002 ; 90 \mathrm{mg} / \mathrm{kg}$ WAY-200070: $t(19)=5.02$, $p=0.0001 ; \quad 180 \mathrm{mg} / \mathrm{kg} \quad$ WAY-200070: $\quad t(19)=4.94$, $p<0.0001)$ and in the first 5 min of the interaction, when the hierarchy was being re-established upon reintroduction of the demonstrator to the home cage (oil: $t(21)=2.54$, $p=0.019 ; 30 \mathrm{mg} / \mathrm{kg}$ WAY-200070: $t(20)=3.37, p=0.003$; $90 \mathrm{mg} / \mathrm{kg}$ WAY-200070: $t(19)=6.67, p=0.0001 ; 180 \mathrm{mg} / \mathrm{kg}$ WAY-200070: $t(19)=4.90, p<0.0001$; see Figure $6 c$ ).

Correlations between Dominance Score or Submissive Behavior and the degree or duration of expression of the preference for the demonstrated food yielded no significant relations. When Dominance Scores were controlled for by ANCOVA, the main effect of demonstrated food was no longer significant in the $90 \mathrm{mg} / \mathrm{kg}$ WAY-200070 group at $4 \mathrm{~h}$ (duration: $\mathrm{F}(1,17)=3.55, \quad p=0.077$; frequency: $\mathrm{F}(1,17)=2.60, p=0.126)$. When Agonistic Behavior Received was controlled by ANCOVA, the main effect of demonstrated food was no longer significant in the $90 \mathrm{mg} /$ kg WAY-200070 group at $4 \mathrm{~h}$ (frequency: $\mathrm{F}(1,17)=3.75$, $p=0.070)$. When Submissive Behavior was controlled for by ANCOVA, the main effect of demonstrated food was no longer significant in the $90 \mathrm{mg} / \mathrm{kg} \mathrm{WAY}-200070$ group at $4 \mathrm{~h}$ (frequency: $\mathrm{F}(1,17)=3.89, p=0.065)$. It should be noted that in all of these ANCOVAs, the covariate factor failed to reach significance.

All other social behaviors analyzed showed no significant effect of drug.

Nonsocial behaviors. Total levels of Nonsocial Behavior were not affected by the drug treatment. Some specific aspects of nonsocial behavior were affected. There was an increase in the frequency of Nonsocial Nonlocomotor Behaviors in the $90 \mathrm{mg} / \mathrm{kg}$ WAY-200070 $(U=142.00$, $z=-2.12, \quad p=0.049) \quad$ and $\quad 180 \mathrm{mg} / \mathrm{kg} \quad$ WAY -200070 $(U=127.50, z=-2.34, p=0.020)$, especially at $5-10 \mathrm{~min}$ and $25-30 \mathrm{~min}(90 \mathrm{mg} / \mathrm{kg}$ WAY-200070: 5-10 $\mathrm{min}, U=$ $127.50, \quad z=-1.83, \quad p=0.020 ; \quad 25-30 \mathrm{~min}, \quad U=122.50$, $z=-2.07, p=0.014 ; 180 \mathrm{mg} / \mathrm{kg}$ WAY-200070: 5-10 min, $U=123.5, \quad z=-2.92, \quad p=0.015 ; \quad 25-30 \mathrm{~min}, \quad U=96.00$, $z=-1.96, p=0.002)$. Similar results were shown in the analysis of the duration of Nonsocial Nonlocomotor Behaviors. The $180 \mathrm{mg} / \mathrm{kg}$ WAY-200070 had a stronger effect than the $90 \mathrm{mg} / \mathrm{kg}$ WAY-200070, as the $180 \mathrm{mg} / \mathrm{kg}$ WAY-200070 group showed a significantly longer duration of Nonsocial Nonlocomotor Behaviors than the $90 \mathrm{mg} / \mathrm{kg}$ WAY-200070 group in the first $5 \mathrm{~min} \quad(U=120.00$, $z=-2.16, p=0.030)$.

Of the two Nonsocial Nonlocomotor Behaviors, Selfgrooming and Solitary Inactivity, the latter appears to be the affected behavior (see Figure $6 \mathrm{~d} ; \chi^{2}(3)=8.17, p=0.043$ ), particularly at $5-10 \mathrm{~min}\left(\chi^{2}(3)=9.71, p=0.021\right)$ and $20-$ $25 \min \left(\chi^{2}(3=11.44, p=0.010)\right.$. These effects appear to be largely caused by increased Solitary Inactivity in the $90 \mathrm{mg} / \mathrm{kg}$ WAY-200070 dose $(U=128.00, z=-2.32, p=0.021)$, especially at $5-10 \mathrm{~min}(U=115.00, z=-2.67, p=0.008)$, and in the $180 \mathrm{mg} / \mathrm{kg}$ WAY-200070 dose $(U=118.00, z=-2.57$, $p=0.010)$, principally at $15-25 \mathrm{~min}(15-20 \mathrm{~min}: U=136.00$, $z=-2.15, \quad p=0.032 ; 20-25 \mathrm{~min}: \quad U=103.00, \quad z=-2.95$, $p=0.0003$; see Figure $6 \mathrm{~d}$ ). The other Nonsocial Nonlocomotor Behavior, Self-Grooming, was not affected by the drug treatment.

Digging was also affected by treatment at $15-20 \mathrm{~min}$ $\left(\chi^{2}(3)=9.17, p=0.027\right)$. This seems to be largely due to an increase in Digging by the $30 \mathrm{mg} / \mathrm{kg}$ WAY-200070 dose during this interval $(U=176.00, z=-2.40, p=0.016)$. All other nonsocial behaviors analyzed were not affected by the drug treatment.

Vaginal smears revealed that all mice were in diestrus, and not cycling, showing that treatment with WAY-200070 did not affect the vaginal cytology of the ovx mice. 


\section{DISCUSSION}

Ovariectomized (ovx) mice treated with the middle or high dose of the ER $\alpha$ agonist PPT did not show a preference for the demonstrated food, while ovx mice treated with the middle dose of the ER $\beta$ agonist WAY-200070 preferred the demonstrated food for twice as long as control mice and mice treated with the low and high doses of WAY-200070. These results cannot be explained by drug effects on food intake, overall activity level, or time spent in oronasal investigation. However, WAY-200070 may be affecting the length of the preference for the demonstrated food through an increase in the subordination of the observers to their demonstrator.

\section{Effects of PPT}

The results of Experiment 1 indicate that the ER $\alpha$ agonist PPT impairs performance on the STFP task, particularly at the $0.05 \mathrm{mg} / \mathrm{kg}$ and $0.1 \mathrm{mg} / \mathrm{kg}$ doses. Galef et al (1988) have shown that smelling the food odor in combination with the breath of the demonstrator is essential for acquiring the preference for the demonstrated food, and this requires sniffing of the mouth area. In this experiment, there were no meaningful effects of PPT on the amount of oronasal investigation, and thus the inhibitory effects of PPT on social learning cannot be explained by an effect on this behavior. Additionally, olfaction appears to be unaffected by $\mathrm{ER} \alpha$, as $\alpha \mathrm{ERKO}$ mice show normal olfactory-dependent behavior (Kavaliers et al, 2005a). Our results also cannot be explained by decreased activity levels, or effects on social dominance, as the mice that received PPT were not significantly different from the mice in the control group on any of these behaviors. While it is interesting to note that PPT reduced approaching and/or attending to the demonstrator, possibly suggesting a reduced motivation to attend to a social stimulus, there were no effects of PPT on the amount of time spent in social interaction with the demonstrator.

The very limited effects of PPT on social interaction suggest that PPT has not impaired the social transmission of food preferences through social mechanisms. Our results are consistent with the results of a number of other, nonsocial, learning studies, in which both $\beta$ ERKO mice given estrogen and mice given $\mathrm{ER} \alpha$ agonists showed impaired spatial learning in the Morris water maze task (eg Rissman et al, 2002; Rhodes and Frye, 2006; Fugger et al, 1998). While further studies are needed before a definite conclusion on whether PPT has blocked the acquisition, expression, motivation, or some other aspect of the STFP can be reached, these results collectively suggest that activation of $\mathrm{ER} \alpha$ causes an impairment in both spatial and social learning performance.

Since the STFP is a hippocampus-dependent type of learning (Alvarez et al, 2002), the inhibitory effects of PPT in the present study may be mediated by action on hippocampal plasticity and memory functions. ER $\alpha$ is present in both the pyramidal cells and the interneurons of the hippocampus (Shugrue and Merchenthaler, 2000), and its activation has been shown to inhibit the phosphorylation of extracellular signal-regulated kinase (ERK), an element of the mitogen-activated protein kinase cascade
(Singh et al, 2000). ERK phosphorylation has been implicated in the formation of both short- and long-term memories in fear-mediated, spatial, food-reward and other hippocampus-dependent tasks (eg Igaz et al, 2006; Atkins et al, 1998; Ribeiro et al, 2005; Hebert and Dash, 2004). It is therefore possible that the present and previous results (eg Rissman et al, 2002; Rhodes and Frye, 2006; Fugger et al, 1998), showing impairing effects of $\mathrm{ER} \alpha$ agonists on hippocampal-dependent learning tasks, are due to the inhibition of ERK phosphorylation. This would not involve classical nuclear actions of $\mathrm{ER} \alpha$, but would be mediated by transmembrane receptor effects on downstream effector mechanisms involved in hippocampal synaptic activity and plasticity (Vasudevan and Pfaff, 2007). Further investigations on the role of ER $\alpha$ on hippocampal plasticity and memory functions are needed before this proposed mode of action of PPT can be elucidated.

\section{Effects of WAY-200070}

The results of Experiment 2 indicate that, in the STFP paradigm, the ER $\beta$ agonist WAY-200070 prolonged the length of a preference for the demonstrated food at the $90 \mathrm{mg} / \mathrm{kg}$ dose. This suggests that $\operatorname{ER} \beta$ plays a role in the acquisition, retention, and/or expression of a socially acquired food preference. Interestingly, only the $90 \mathrm{mg} / \mathrm{kg}$ WAY-200070 dose but not the higher and lower doses of WAY-200070 produced this effect. This suggests that WAY200070 may have an inverted U-shaped dose-response curve, possibly due to the high dose binding to $\mathrm{ER} \alpha$ as well as to $\operatorname{ER} \beta$. $\operatorname{ER} \alpha$ and $\operatorname{ER} \beta$ frequently act in opposition to each other (Gustafsson, 2006), and since our results indicate that $\mathrm{ER} \alpha$ seems to impair the learned preferences, WAY-200070 binding to ER $\alpha$ may counter the effects of binding to ER $\beta$. This would also be in agreement with our previous results showing that estradiol has a similar dose-response curve on wheel-running activity (unpublished data). Alternatively, our results may be due to low statistical power, as suggested by the fact that the preference for the demonstrator's food expressed by the observers that had received the $180 \mathrm{mg} / \mathrm{kg}$ dose of WAY-200070 almost reached statistical significance $(p=0.092)$. Clearly, further research with this novel compound is needed before a conclusion on the inverted U-shaped dose response can be reached.

As with PPT, the WAY-200070-induced prolonging of a socially acquired preference could not be accounted for by increased oronasal investigation by the observers, as the two groups showing a prolonged food preference showed no more oronasal or Social Investigation than any other group. In fact, the $180 \mathrm{mg} / \mathrm{kg}$ WAY-200070 group actually showed less Social Investigation in the first $5 \mathrm{~min}$ of the social interaction than the groups which maintained the preference for the same period of time. $\operatorname{ER} \beta$ also appears not to affect olfaction, as $\beta$ ERKO mice are not impaired in olfaction (Kavaliers et al, 2005a). Additionally, our results on social learning cannot be accounted for by heightened activity or more time spent in contact with the demonstrator, as the $90 \mathrm{mg} / \mathrm{kg}$ WAY-200070-treated mice were no more active or social than the other groups.

Our results are in agreement with studies using $\beta$ ERKO mice that show that physiological doses of estrogens caused deficits on nonsocial learning tasks, which suggests that 
$\operatorname{ER} \beta$ may be necessary for the acquisition of the task (Rissman et al, 2002). Additionally, female rats given a diet rich in $\operatorname{ER} \beta$ selective phytoestrogens outperformed females given a phytoestrogen-poor diet on the radial arm maze (Lephart et al, 2002). The $\mathrm{ER} \beta$ selective agonists coumestrol and diarylpropionitrile have also been shown to improve performance on the Morris water maze (Rhodes and Frye, 2006). This suggests that, in the current study, the selective activation of $\operatorname{ER} \beta$ may have directly fostered learning of and/or memory for a socially acquired food preference, rather than through, or possibly together with, other motivational aspects of this learning paradigm.

It is interesting to note that the group of observers showing prolonged socially acquired food preferences (90 mg/kg WAY-200070) had a lower dominance score, received more agonistic behavior, and showed increased submissive behavior. One may hypothesize that the increased social submission in the 90 and $180 \mathrm{mg} / \mathrm{kg}$ WAY-200070-treated mice could have facilitated the longer maintenance of the preference for the demonstrated food. Subordinate mice may be more inclined to acquire a food preference from a dominant demonstrator. Social dynamics do affect social learning, and in deer mice, for example, observers will learn better from a dominant demonstrator than from a subordinate one (Kavaliers et al, 2005b). If an animal is dominant, it is likely in better health and stronger than its subordinates, and therefore likely to be consuming high-quality food, making it a good model from whom to acquire a food preference. This would parallel results from previous studies in which an adult mouse is a more effective demonstrator than one or many mouse pups, inducing a longer-lasting preference in another adult mouse (Choleris et al, 1997). As pups and juveniles are typically subordinate to mothers and other adults, one may hypothesize that dominant mice are better demonstrators. In the present study, increased subordination in the observers that received the 90 and $180 \mathrm{mg} / \mathrm{kg}$ doses of WAY-200070 might thus explain the prolonged preference for the demonstrated food expressed by the $90 \mathrm{mg} / \mathrm{kg}$ of WAY-200070 group. While direct correlations between received agonistic behavior or Submissive Behavior and the duration of the food preference were not found, analysis of covariance indicates that increased subordination may be responsible for the observed effects of WAY-200070 at $90 \mathrm{mg} / \mathrm{kg}$ on the length of expression of the food preference. WAY-200070's effects on social learning may thus be two-fold; it may prolong it by increasing the level of subordination of the observer mice, as well as by directly affecting learning mechanisms in the brain.

The shorter preference for the demonstrated food shown by the ovariectomized (ovx) oil and 30 and $180 \mathrm{mg} / \mathrm{kg}$ WAY-200070 groups closely resemble that of estrus females (Clipperton et al, 2006), who have low levels of estrogens (Walmer et al, 1992). WAY-200070 at $90 \mathrm{mg} / \mathrm{kg}$ prolonged the maintenance of the socially acquired food preference by these ovx mice to a level akin to that shown by intact females in proestrus and diestrus (Clipperton et al, 2006), when estrogen levels are higher and progesterone levels are low (Walmer et al, 1992). This, in conjunction with the present results, suggests that the longer-maintained preference for the demonstrated food seen in proestrus and diestrus females may be a result of the action of estrogens on $\operatorname{ER} \beta$ countering those on $\mathrm{ER} \alpha$, either directly or through effects on subordination.

Estrogens can facilitate learning through a number of mechanisms, including the induction of new synapses, the decrease of GABAergic inhibition and glutamate decarboxylase (GAD) expression, and the increase of the density of dendritic spines and NMDA receptors (for a review, see McEwen, 2002), as well as the enhancement of synaptic long-term potentiation (LTP; Córdoba Montoya and Carrer, 1997). In mice, $\mathrm{ER} \beta$ is highly expressed in the parahippocampal region, predominant in the diagonal band of Broca, and in the hippocampus proper (Mitra et al, 2003; Merchenthaler et al, 2004), all areas which have been implicated in memory of the STFP (Alvarez et al, 2002; Vale-Martinez et al, 2002). This suggests that the facilitatory effects of WAY-200070 could be through some of the mechanisms that have been described for estradiol (for a review, see McEwen, 2002), and that some of the actions of estradiol on these mechanisms are through $\mathrm{ER} \beta$. This would be consistent with lesion studies in rats showing the involvement of the hippocampal system, the parahippocampal region, and the cholinergic basal forebrain in the STFP (Vale-Martinez et al, 2002). Our results, where an $\operatorname{ER} \beta$ agonist prolonged a just-acquired food preference, support the notion that $\operatorname{ER} \beta$ in the parahippocampal region or cholinergic basal forebrain may be involved in social learning. Whether $\operatorname{ER} \beta$ is also involved in the retrieval of a previously learned preference remains to be determined.

Alternatively, the prolonged preference could be mediated through WAY-200070 affecting the dopamine (DA) system. DA has been shown to affect LTP and learning in the hippocampus and the basolateral amygdala, two areas involved in the STFP, as well as other regions (eg O'Carroll et al, 2006; Thompson et al, 2005; Floresco and Tse, 2007; LeDoux, 2000). DA has been shown to be involved in social learning, as studies in mice have found that dopamine acting on the D1 but not the D2 dopamine receptor mediates the STFP (Choleris et al, in preparation). Mesocorticolimbic DA projections innervate many of the areas known to be involved in the STFP, such as the hippocampal region, the orbitofrontal cortex, and the amygdala (eg Bunsey and Eichenbaum, 1995; Alvarez et al, 2001; Sánchez-Andrade et al, 2005; Ross et al, 2005; Wang et al, 2007). The dopaminergic system is modulated by estrogens, both through increasing the release of DA (McDermott et al, 1994; Liu and Xie, 2004) and through decreasing the expression and activity of the DA transporter, which eliminates DA from the extracellular space (Karakaya et al, 2007). The modulation of DA release is likely mediated by $\operatorname{ER} \beta$, which is strongly expressed in the ventral tegmental area, whereas $\mathrm{ER} \alpha$ is not (Mitra et al, 2003). This suggests that WAY-200070 may be prolonging the preference for the demonstrated food through an enhancement of the activity of the mesocorticolimbic DA system. This may explain the observed effects of WAY200070 on the social interactions as well as possible direct effects on learning per se.

\section{Overall Conclusions}

As social recognition is enhanced by estrogens (Tang et al, 2005), and studies with KO mice have shown that $\operatorname{ER} \beta$ is 
important for social recognition (eg Choleris et al, 2003, 2006), one may hypothesize that WAY-200070-induced improvement in social recognition may have contributed to the prolonged expression of the preference for the demonstrated food. This is further supported by studies investigating the STFP in Mongolian gerbils, which have found that they will only learn from relatives or from familiar conspecifics (eg Valsecchi et al, 1996), suggesting that social recognition may play a key role in social learning. However, if this was the case, one would expect that the activation of both $\operatorname{ER} \alpha$ and $\operatorname{ER} \beta$ would either improve or not affect social learning, as both $\alpha \mathrm{ERKO}$ and $\beta$ ERKO mice are impaired in social recognition (eg Choleris et al, 2003, 2006). In this study, though, we found that the $\mathrm{ER} \alpha$ agonist PPT actually blocked the socially learned food preference. It therefore seems unlikely that the effects of PPT and WAY-200070 on social learning were mediated solely by effects on the social recognition of the mice.

Instead, our results show a distinct parallel to those seen in other studies of nonsocial learning (eg Fugger et al, 1998; Rissman et al, 2002, 1997; Rhodes and Frye, 2006), in that the ER $\alpha$ agonist PPT impaired social learning, while the ER $\beta$ agonist WAY-200070 produced a prolonged preference. Numerous control studies have shown that the STFP is a specifically social form of learning (eg Valsecchi and Galef, 1989; Choleris et al, in preparation), and our results suggest that, while the actions of PPT are unlikely to be affecting the social aspects of the task, WAY-200070 may be affecting the STFP by mediating subordinate behavior.

$\operatorname{ER} \alpha$ and $\operatorname{ER} \beta$ may be influencing the learning and/or memory for a socially learned food preference by acting on different aspects of the formation of hippocampus-dependent memory. ER $\alpha$ may be impairing learning through its inhibition of ERK phosphorylation, a critical component of the formation of hippocampus-dependent memory (Singh et al, 2000; Igaz et al, 2006; Atkins et al, 1998; Hebert and Dash, 2004). $\mathrm{ER} \beta$, conversely, may prolong the preference by facilitating LTP, similar to the actions of estrogens (Córdoba Montoya and Carrer, 1997; McEwen, 2002). Alternatively, $\operatorname{ER} \beta$ could be prolonging the preference for the demonstrated food through an activation of the dopaminergic system (McDermott et al, 1994; Karakaya et al, 2007), which has been shown to mediate social learning in female mice (Choleris et al, in preparation), or by increasing levels of subordination, which has been shown to improve learning in some species (Kavaliers et al, 2005b). Clearly, more studies are needed to tease apart direct roles played by $\mathrm{ER} \beta$ in learning and memory from those played in social interactions.

Our results, as well as those of previous studies, suggest that $\mathrm{ER} \alpha$ could be impairing the memory for the socially acquired food preference, while $\operatorname{ER} \beta$ could be enhancing the acquisition of the task, possibly through an effect on subordination. This fits well with the fact that $\operatorname{ER} \alpha$ and $\operatorname{ER} \beta$ act in opposition to each other in their control of a number of physiological and behavioral processes (Gustafsson, 2006; Ogawa et al, 2004). Elucidating the involvement of estrogens and their receptors in aspects of social cognition will prove especially useful as the 'baby boom' generation ages and an increasing number of women are placed on hormone replacement therapy (Shumaker et al, 2003).

\section{ACKNOWLEDGEMENTS}

We thank Scott McGrath, Kathryn Williams, James Slough, Violet Zawada, and Sebastian Diaz-Gonzalez for their help with data collection. We also thank Craig Allen and two anonymous reviewers for useful advice on the manuscript, and C Richard Lyttle and Heather A Harris for providing WAY-200070.

\section{DISCLOSURE/CONFLICT OF INTEREST}

The authors declare that this work was funded by NIH HD 05751, MH 38273, NSERC 045881, and in part by the Wyeth Pharmaceuticals. The authors declare that, except for income received from their primary employer, no financial support or compensation has been received from any individual or corporate entity over the past 3 years for research or professional service and there are no personal financial holdings that could be perceived as constituting a potential conflict of interest.

\section{REFERENCES}

Alvarez P, Lipton PA, Melrose R, Eichenbaum H (2001). Differential effects of damage within the hippocampal region on memory for a natural, nonspatial odor-odor association. Learn Mem 8: 79-86.

Alvarez P, Wendelken L, Eichenbaum H (2002). Hippocampal formation lesions impair performance in an odor-odor association task independently of spatial context. Neurobiol Learn Mem 78: $470-476$.

Archer J (1988). The Behavioral Biology of Aggression. Cambridge University Press: New York.

Atkins CM, Selcher JC, Petraitis JJ, Trzaskos JM, Sweatt JD (1998). The MAPK cascade is required for mammalian associative learning. Nat Neurosci 1: 602-609.

Berger-Sweeney J, Steams NA, Frick KM, Beard B, Baxter MG (2000). Cholinergic basal forebrain is critical for social transmission of food preferences. Hippocampus 10: 729-738.

Bunsey M, Eichenbaum H (1995). Selective damage to the hippocampal region blocks long-term retention of a natural and nonspatial stimulus-stimulus association. Hippocampus 5: 546-556.

Chesler EJ, Juraska JM (2000). Acute administration of estrogen and progesterone impairs the acquisition of the spatial morris water maze in ovariectomized rats. Horm Behav 38: 234-242.

Choleris E, Gray D, Diaz-Gonzalez S, Clipperton AE, Welsman RG Differential effects of dopamine D1 and D2 antagonists on social learning of food preferences and feeding in mice (in preparation).

Choleris E, Guo C, Liu H, Mainardi M, Valsecchi P (1997). The effect of demonstrator age and number on duration of sociallyinduced food preferences in house mouse (Mus domesticus). Behav Process 41: 69-77.

Choleris E, Gustafsson J- $\AA$, Korach KS, Muglia LJ, Pfaff DW, Ogawa S (2003). An estrogen dependent micronet mediating social recognition: a study with oxytocin- and estrogen receptor aand b-knockout mice. Proc Natl Acad Sci USA 100: 6192-6197.

Choleris E, Kavaliers M, Pfaff DW (2004). Functional genomics of social recognition. J Neuroendocrinol 16: 383-389.

Choleris E, Ogawa S, Kavaliers M, Gustafsson J-Å, Korach KS, Muglia LJ et al (2006). Involvement of estrogen receptor $\alpha, \beta$ and oxytocin in social discrimination: a detailed behavioral analysis with knockout female mice. Genes Brain Behav 5: 528-539.

Choleris E, Valsecchi P, Wang Y, Ferrari P, Kavaliers M, Mainardi M (1998). Social learning of a food preference in male 
and female Mongolian gerbils is facilitated by the anxiolytic chlordiazepoxide. Pharmacol Biochem Behav 60: 575-584.

Clipperton AE, Diaz-Gonzalez SB, Gray D, Choleris E (2006). The effect of gonadal hormones on the social transmission of food preferences. 2006 Society for Neuroscience Abstract Viewer/ Itinerary Planner: 752.1.

Córdoba Montoya DA, Carrer HF (1997). Estrogen facilitates induction of long term potentiation in the hippocampus of awake rats. Brain Res 778: $430-438$.

Cragg CL, Pfaff DW, Choleris E (2007). Effects of estrogen receptor alpha and beta specific agonists on social recognition in mice (in preparation).

Daniel JM (2006). Effects of oestrogen on cognition: what have we learned from basic research? J Neuroendocrinol 18: 787-795.

Davis DM, Jacobson TK, Aliakbari S, Mizumori SJY (2005). Differential effects of estrogen on hippocampal- and striataldependent learning. Neurobiol Learn Mem 84: 132-137.

Floresco SB, Tse MT (2007). Dopaminergic regulation of inhibitory and excitatory transmission in the basolateral amygdalaprefrontal cortical pathway. J Neurosci 27: 2045-2057.

Fugger HN, Cunningham SG, Rissman EF, Foster TC (1998). Sex differences in the activational effect of $\mathrm{ER} \alpha$ on spatial learning. Horm Behav 34: 163-170.

Galef Jr BG (1996). Social enhancement of food preferences in Norway rats: a brief review. In: Heyes CM, Galef Jr BG (eds). Social Learning in Animals: The Roots of Culture. Academic Press, Inc.: San Diego, CA. pp 49-64.

Galef Jr BG, Mason JR, Preti G, Bean NJ (1988). Carbon disulfide: a semiochemical mediating socially-induced diet choice in rats. Physiol Behav 42: 119-124.

Galef Jr BG, Wigmore SW (1983). Transfer of information concerning distant foods: a laboratory investigation of the 'information-centre' hypothesis. Anim Behav 31: 748-758.

Grant EC, Mackintosh JH (1963). A comparison of the social postures of some common laboratory rodents. Behavior 21: 246-259.

Gustafsson J (2006). ER $\beta$ scientific visions translate to clinical uses. Climacteric 9: 156-160.

Hebert AE, Dash PK (2004). Nonredundant roles for hippocampal and entorhinal cortical plasticity in spatial memory storage. Pharmacol, Biochem Behav 79: 143-153.

Igaz LM, Winograd M, Cammarota M, Izquierdo LA, Alonso M, Izquierdo I et al (2006). Early activation of extracellular signalregulated kinase signaling pathway in the hippocampus is required for short-term memory formation of a fear-motivated learning. Cell Mol Neurobiol 26: 989-1002.

Imwalle DB, Scordalakes EM, Rissman EF (2002). Estrogen receptor $\alpha$ influences socially motivated behaviors. Horm Behav 42: 484-491.

Karakaya S, Kipp M, Beyer C (2007). Oestrogen regulates the expression and function of dopamine transporters in astrocytes of the nigrostriatal system. J Neuroendocrinol 19: 1-9.

Kavaliers M, Choleris E, Pfaff DW (2005a). Recognition and avoidance of the odors of parasitized conspecifics and predators: differential genomic correlates. Neurosci Biobehav Rev 29: 1347-1359.

Kavaliers M, Colwell DD, Choleris E (2005b). Kinship, familiarity and social status modulate social learning about 'micropredators' (biting flies) in deer mice. Behav Ecol Sociobiol 58: 60-71.

Korol DL (2004). Role of estrogen in balancing contributions from multiple memory systems. Neurobiol Learn Mem 82: 309-323.

Korol DL, Malin EL, Borden KA, Busby RA, Couper-Leo J (2004). Shifts in preferred learning strategy across the estrous cycle in female rats. Horm Behav 45: 330-338.

Kuiper GG, Enmark E, Pelto-Huikko M, Nilsson S, Gustafsson J (1996). Cloning of a novel receptor expressed in rat prostate and ovary. Proc Natl Acad Sci USA 93: 5925-5930.

Latham N, Mason G (2004). From house mouse to mouse house: the behavioural biology of free-living Mus musculus and its implications in the laboratory. Appl Anim Behav Sci 86: 261-289.

LeDoux JE (2000). Emotion circuits in the brain. Annu Rev Neurosci 23: 155-184.

Lephart ED, West TW, Weber KS, Rhees RW, Setchell KDR, Adlercreutz $\mathrm{H}$ et al (2002). Neurobehavioral effects of dietary soy phytoestrogens. Neurotoxicol Teratol 24: 5-16.

Liu B, Xie J (2004). Increased dopamine release in vivo by estradiol benzoate from the central amygdaloid nucleus of Parkinson's disease model rats. J Neurochem 90: 654-658.

Malamas MS, Manas ES, McDevitt RE, Gunawan I, Xu ZB, Collini MD et al (2004). Design and synthesis of aryl diphenolic azoles as potent and selective estrogen receptor-beta ligands. J Med Chem 47: 5021-5040.

McDermott JL, Liu B, Dluzen DE (1994). Sex differences and effects of estrogen on dopamine and DOPAC release from the striatum of male and female CD-1 mice. Exp Neurol 125: 306-311.

McEwen B (2002). Estrogen actions throughout the brain. Recent Prog Horm Res 57: 357-384.

Merchenthaler I, Lane MV, Numan S, Dellovade TL (2004). Distribution of estrogen receptor $\alpha$ and $\beta$ in the mouse central nervous system: in vivo audioradiographic and immunocytochemical analyses. J Comparat Neurol 473: 270-291.

Mitra SW, Hoskin E, Yudkovitz J, Pear L, Wilkinson HA, Hayashi S et al (2003). Immunolocalization of estrogen receptor $\beta$ in the mouse brain: comparison with estrogen receptor $\alpha$. Endocrinology 144: 2055-2067.

O’Carroll CM, Martin SJ, Sandin J, Frenguelli B, Morris RG (2006). Dopaminergic modulation of the persistence of one-trial hippocampus-dependent memory. Learn Mem 13: 760-769.

Ogawa S, Choleris E, Pfaff DW (2004). Genetic influences on aggressive behaviors and arousability in animals. Ann NY Acad Sci 1036: 257-266.

Rhodes ME, Frye CA (2006). ER $\beta$-selective SERMs produce mnemonic-enhancing effects in the inhibitory avoidance and water maze tasks. Neurobiol Learn Mem 85: 183-191.

Ribeiro MJ, Schofield MG, Kemenes I, O'Shea M, Kemenes G, Benjamin PR (2005). Activation of MAPK is necessary for longterm memory consolidation following food-reward conditioning. Learn Mem 12: 538-545.

Rissman EF, Heck AL, Leonard JE, Shupnik MA, Gustafsson J (2002). Disruption of estrogen receptor beta gene impairs spatial learning in female mice. Proc Natl Acad Sci USA 99: 3996-4001.

Rissman EF, Wersinger SR, Taylor JA, Lubahn DB (1997). Estrogen receptor function as revealed by knockout studies: neuroendocrine and behavioral aspects. Horm Behav 31: 232-243.

Ross RS, McGaughy J, Eichenbaum H (2005). Acetylcholine in the orbitofrontal cortex is necessary for the acquisition of a socially transmitted food preference. Learn Mem 12: 302-306.

Sánchez-Andrade G, James BM, Kendrick KM (2005). Neural encoding of olfactory recognition memory. J Reprod Dev 51: 547-558.

Shugrue PJ, Lane MV, Merchenthaler I (1997). Comparative distribution of estrogen receptor-a and $-\mathrm{h}$ mRNA in the rat central nervous system. J Comparat Neurol 388: 507-525.

Shugrue PJ, Merchenthaler I (2000). Evidence for novel estrogen receptor binding sites in the rat hippocampus. Neuroscience 99: 605-612.

Shumaker SA, Legault C, Rapp SR, Thal L, Wallace RB, Ockene JK et al (2003). Estrogen plus progestin and the incidence of dementia and mild cognitive impairment in postmenopausal women. JAMA 289: 2651-2662.

Singh M, Sétáló Jr G, Guan X, Frail DE, Toran-Allerand CD (2000). Estrogen-induced activation of the mitogen-activated protein kinase cascade in the cerebral cortex of estrogen receptor- $\alpha$ knock-out mice. J Neurosci 20: 1694-1700.

Stauffer SR, Coletta CJ, Tedesco R, Nishiguchi G, Carlson K, Sun J et al (2000). Pyrazole ligands: structure-affinity/activity 
relationships and estrogen receptor-alpha-selective agonists. J Med Chem 43: 4934-4947.

Tang AC, Nakazawa M, Romeo RD, Reeb BC, Sisti H, McEwen BS (2005). Effects of long-term estrogen replacement on social investigation and social memory in ovariectomized C57BL/6 mice. Horm Behav 47: 350-357.

Thompson AM, Swant J, Wagner JJ (2005). Cocaine-induced modulation of long-term potentiation in the CA1 region of rat hippocampus. Neuropharmacology 49: 185-194.

Vale-Martinez A, Baxter MG, Eichenbaum H (2002). Selective lesions of basal forebrain cholinergic neurons produce anterograde and retrograde deficits in a social transmission of food preference task in rats. Eur J Neurosci 16: 983-998.

Valsecchi P, Choleris E, Moles A, Guo C, Mainardi M (1996). Kinship and familiarity as factors affecting social transfer of food preferences in adult Mongolian gerbils (Meriones unguiculatus). J Comparat Psychol 10: 243-251.
Valsecchi P, Galef Jr BG (1989). Social influences on the food preferences of house mice (Mus musculus). Int J Comparat Psychol 2: 245-256.

Vasudevan N, Pfaff DW (2007). Membrane-initiated actions of estrogens in neuroendocrinology: emerging principles. Endocr Rev 28: 1-19.

Walf AA, Frye CA (2005). ER $\beta$-selective estrogen receptor modulators produce antianxiety behavior when administered systemically to ovariectomized rats. Neuropsychopharmacology 30: $1598-1609$.

Walmer DK, Wrona MA, Hughes CA, Nelson KG (1992). Lactoferrin expression in the mouse reproductive tract during the natural estrous cycle: correlation with circulating estradiol and progesterone. Endocrinology 131: 1458-1466.

Wang Y, Fontanini A, Katz DB (2007). Temporary basolateral amygdala lesions disrupt acquisition of socially transmitted food preferences in rats. Learn Mem 13: 794-800. 